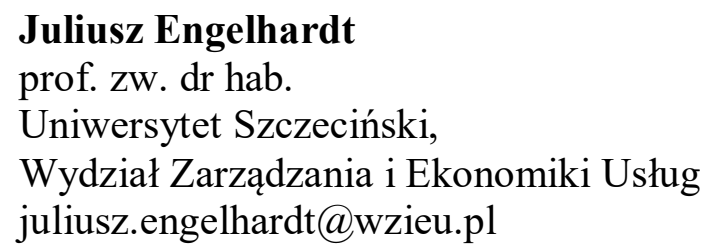

DOI: 10.35117/A_ENG_17_04_06

\title{
The transfer of ownership of Regional Railway to governments provinces 2008-2015. What's next?
}

\begin{abstract}
The paper refers to the history of the transfer voivodship self-government the responsibility for organizing and funding regional railway with the submission in 2008 by the Treasury that local governments ownership of the company's Regional Transport. In 2016, the reform has not yet been fully completed, however the process of transfer the ownership resulted in many positive phenomena in the whole Polish railway transport. In particular, it solved the problem of the location of the target company's Regional Transport on rail passenger market, although in the years 2014 - 2015 could be observed significant improvements in financial and economic situation - this financial company. In the final part of the paper indicated that the current structure of economic and ownership on the Polish rail passenger market can and should undergo further changes and transformations. The target solution is the privatization of companies in the whole rail passenger sector, although it is not will happen quickly, because a significant part of the Polish political class is not prepared for such a solution.
\end{abstract}

Keywords: Decentralization of State, Regional Railway Transportation, The privatization of the Passenger Railway Companies

\section{Origins, assumptions, and realization of the process of regional rail privatization}

Since the late nineties, successive governments have pursued a policy of decentralization of the state, involving the reform of the functioning of local governments (creation in 1998, regional governments, Offices of the District, a constant reinforcement of municipalities and communes) and the transfer of tasks, yet which are the tasks of the government, at the lowest possible level of functioning. The concepts of regional railroad privatization in Poland have been brought about by the 2000 Commercialization Act adopted by the AWS-UW coalition government. Under its regulations, PKP Przewozy Regionalne was established in 2001. It was included in the transitional regulations, which amounts to a subsidy, in which the central subsidies were divided into self-government, and ... immediately after the entry into force of the said Act and after the takeover of the government by the SLD - UP coalition began a great crisis of railway regional transport in Poland. PKP Regional Transport Company did not receive budget subsidies within the level specified in the Act. For several years, the company was balancing on its solvency boundary, its indebtedness to other PKP S.A. companies increased steadily until the crisis in 2003 when it announced it was planning to implement a program to reduce more than 1,000 regional trains. This resulted in widespread protests and a strong resistance from trade unions. As a result, the intention was withdrawn and the PKP companies were forced to conclude a restructuring agreement with PKP Regional Transport Company, with a $45 \%$ reduction in debt. The "new opening" took place in 2004, when the central subsidy for regional rail transport was liquidated and since that time, the Province Self-governments began to subsidize these transports from their own revenues as the so-called own task. This change did not, however, contribute to a significant reduction of the deficit of 
PKP Przewozy Regionalne. On the wave of problems with financing regional railway transport, the largest Polish self-governmental province, ie the Mazovian Province, decided to set up its own company for the implementation of rail transport. Mazowieckie railways started shipping on 1 January 2005.

In the situation of high debt repurchase of PKP Przewozy Regionalne Government began to look for new solutions, and in the environment connected with railway and in the media has rekindled the discussion. It was discussed for a long time, three years, and the main problems were: the necessity of another debt of PKP Przewozy Regionalne, the proposal of the division of the company into 5 or even 15 smaller companies operating provinces, the target location of inter-voyages and the ownership of Przewozy Regionalne. In the course of the discussion on the privatization in 2005-2007, some provinces (e.g. Wielkopolska, Dolnośląskie, and Śląskie) reported willingness to set up - in the form of Mazovia - their own companies to perform regional railway transport, with the Mazowieckie Railway property and employment of PKP Przewozy Regionalne). All these topics have been discussed in the previously mentioned publication. In 2006, the Ministry of Infrastructure pushed for a debtto-equity option of PKP Przewozy Regionalne, but in 2007 it changed its position and finally agreed with the option written in the version of the document "Strategy for rail transport until 2013" adopted by the Council of Ministers. In general terms, the concept was implemented: the debt of PKP Przewozy Regional amounted to PLN 2,660 million and repaid from that amount of the company's main creditors and the transfer of shares acquired from PKP S.A. in the PKP Przewozy Regionalne company to the province self-governments, after the previous transfer to the PKP Intercity of the Interstate Transport Division. The course of the entire process of privatization has been regulated by law. It must be emphasized, however, that the creation of the relevant statutory provisions was only a preliminary step in the actual privatization of regional rail transport. The Marshals of the Provinces at numerous conventions and through the media reported a number of remarks, objections, demands and demands for this process. In general, province self-governments were not satisfied with the statutory provisions guaranteeing PLN 2160m only for PKP Przewozy Regionalne's debt and, of course, they demanded much more money for the privatization of regional rail transport and, in addition, the transfer of many real estate under the seat of the PR and back office of PKP SA. maintenance of rolling stock. Negotiations of the governmental side with the province marshals finally ended at the end of November 2008 and on December 2, 2008, the Council of Ministers adopted a resolution on the financing of regional passenger rail transport authorizing the Minister of Infrastructure to conclude an agreement with the province authorities with the latter on 9 December 2008. The provinces have signed an agreement with the Minister of Infrastructure, which is, in fact, a repetition of the content of the resolution of the Council of Ministers. The agreement covered two periods: 2009-2015 and 2016-2020, with the second quarter providing for the total amount of PLN $3.85 \mathrm{bn}$ from the state budget and EU programs to finance the investment program for the modernization and purchase of rolling stock. 2009 - 2015 The agreement envisaged a subsidy of PLN 2.25bn, in addition, the government has committed itself to increasing its own revenues from 2010 by increasing its share in corporate income tax (CIT) from $14 \%$ to $14.75 \%$, i.e. by $0.75 \%$ (financial result: additional about PLN 200 million per year on the side of Province Self-governments to cover operating losses of PKP Przewozy Regionalne) and to contribute to the company technical support to operate the rolling stock and other real estate, They committed themselves to contribute in kind to the stock company purchased it (by the Marshals of the provinces) from the state budget funds (from the Railway Fund and the budget reserve). These allowances were intended to cover the balance sheet loss of PKP Przewozy Regionalne from previous years in the amount of PLN 1188 million. In general, the agreement of 9 December 2008 was 
very beneficial for the province self-governments and from the point of view of providing financial means for the entire process of privatization.

It should be emphasized here that the transport of the regional railways' privatization carried out in 2008 has its critics, who argue their arguments until today - details are contained in the author's published publication.

Since 2009 the government has consistently fulfilled its obligations towards the Marshals of the provinces - the share of local governments in the CIT was increased by $0.75 \%$, the funds for railway investments were raised from the Railway Fund, and 26 companies with a market value of 268.2 million In 2012, an additional PLN 150 million was allocated for the co-financing of the province's own tasks in the area of organization of regional passenger rail services performed on the basis of public service contracts.

According to the author, the privatization of regional railways has resulted in a number of positive effects, which have taken place in the entire Polish railway system and directly in the rail passenger transport sector in the regions, and can be included among others:

$>$ finalization of property division in the PKP group in scope of the target equipment of carriers in locomotives and workshop facilities,

$>$ Completion of the division of the professional group of train drivers between railway carriers,

> PKP Cargo SA granted PKP Cargo SA a debt of PLN 600m, which allowed the company to survive the crisis of 2009 and financed from its own funds a broad voluntary departure program, followed by deep internal restructuring.,

$>$ The privatization of PKP Cargo SA via the stock exchange was completed at the end of 2013 , but it was made possible in 2008 by the division of traction, workshop and train drivers and the restructuring process from 2009 to 2010 ,

$>$ Positive development of the railway segment of inter-governmental transport thanks to its location in PKP Intercity - the transfer of this segment from PKP Przewozy Regionalne to PKP Intercity was, contrary to critics' opinion, a strategic decision for the whole railway market in Poland. This segment is currently developing very dynamically and leaving it in PKP Przewozy Regionalne was associated with the risk of its total recession,

$>$ the implementation by the province marshals of a broad investment program in the scope of purchase of new rolling stock for the realization of railway regional transport, whose overall value in 2015 exceeded significantly 5 billion PLN,

$>$ the implementation of the program of modernization of old rolling stock by the marshals of the province by purchasing it from the Regional Transport Company and refurbishing it at its own expense,

$>$ the ability of the province marshals to carry out their own policy on the subject structure in regional railway transport - the creation of own railway carriers on the basis of the government's subsidized rolling stock support or alternatively announcing open tenders for regional transport, entrusting the selected hauler with its own rolling stock,

$>$ noticeable improvement of the transport offer at the level of some regions (e.g. Zachodniopomorskie, Pomorskie, Lubuskie, Wielkopolskie, Dolnośląskie, Małopolskie and several others) despite general problems with the functioning of the PR company, which was possible thanks to the purchase of modern rolling stock and making it available to the company,

$>$ full success of the Regional Operational Program (ROP) from the budget perspective 2007 - 2013 in the field of railway investments, which allowed to increase the funds of the provinces for the purchase of new rolling stock, which is now skillfully discounted by the Marshals propagandist and politically, 
full success of the ROP from the budget perspective 2007-2013 in the area of investments in regional railway infrastructure, with the government providing funds from the Railway Fund for the so- "Own contribution" of the beneficiary. Infrastructure projects of the ROP are a result of the process of self-government since the issues of railway infrastructure were an important topic of negotiations between the government and marshals of the provinces in 2008,

$>$ the overall improvement of the image turn regions in the public eye - in spite of all the difficulties with the company PR - made possible by the restoration of many rail connections at the initiative of the Marshals (on the upgraded infrastructure) and the use of the transport of modern rolling stock as well as through the implementation of the government program for the modernization of railway stations, which It also included smaller regional stations (the last item was also strongly articulated by the marshals in the negotiations of 2008).

The above-mentioned positive effects of the governmental coalition of the PO-PSL organized by the governmental coalition of regional railways are generally not noticed by the fierce opponents of this process or suppressed. They do not want to be expected to look objectively at the quality changes that took place after 2008 in the rail transport sector in Poland. They do not see that there are self-government provinces, such as Zachodniopomorskie Province, where $100 \%$ of the rolling stock engaged in regional railway services are new or fully modernized, that the Polish society has accepted this qualitative change on the railways. Their own promotional campaigns are already using this new image of Polish regional railways. Finally, thanks to the large budgetary and EU funds allocated to this process, the Polish rolling stock industry has gained a great impetus for development thanks to orders for regional rolling stock and has already become competitive almost throughout Europe.

\section{Regional Transport Company after the privatization - years 2009 - 2013}

It seems that the lack of objectivity of the critics of the administration, despite the fact that almost eight years have elapsed since the beginning of this process and the fact that it has evident systemic benefits in the whole Polish railway transport, is due to the numerous problems that have occurred since 2009 connected with the operation of the Regional Transport Company. It is possible to agree with the view that if the whole assessment of the long-term process of regional rail transport in Poland is reduced only to the market failure of this company and debt reparation - for the third time in its 15 -year history - it is true that this reform by 2015 has not brought the desired effect. One of the major causes of numerous problems with the functioning of the Regional Transport Company can undoubtedly be a blame on the part of the then government that it underestimated the risk that the Marshals of the Provinces, as part of the co-owners of the company, were not - although as high-level politicians should be - able to "in gremio" to ensure effective ownership control over it, build its own strategy of a nationwide self-government company and effectively carry out the process of its further restructuring and transformation. They preferred to go the other way. "They installed" in the war company the Management Board, whose purpose was not any further reform of the company, but the fight with the government and with PKP Intercity and generally "take" further money from the government. The activity of the Regional Transport Company in 2009-2013 can be characterized by several actions such as unfair competition for the inter-voyage railroad segment in 2009-2010, the fight against the government for additional funds, debt recession, lack of internal restructuring and gradual loss market. Although the company's management declared that it was necessary to conduct further and deep restructuring in those years, it did not carry out such restructuring, as it focused on the external environment. He created legends about the big money owed to the company by the 
government (a process with the government for imagined large sums owed to the company), leaseback (someone had to buy the whole shredded stock, renovate it and then lease it to the company), and actively opposed the government's proposal to introduce the exclusion rules formed on the basis of the former PKP bankruptcy law, which is a requirement of EU law. This was the mall of Marshals of the provinces and the whole environment of unrealistic visions, while the lack of internal reforms in the company was at its price - the Regional Transport Company successively lost its market, which was its core - business, that is the regional transport, and the Marshals had a lot of funds for this period. The camp has started to focus more on the creation and further development of its own companies to carry out regional transport.

One of the co-owners of the company took place at the end of 2012 when a new selfgovernment team was set up, which in 2013 will work out and present the concept of further restructuring of the company Przewozy Regionalne. At the same time, the government has initially declared that it will once again deduct the Regional Transport Company, which was reflected in the inclusion in the bill of the budget amount of PLN 1.2 billion from the budget reserve for this purpose. However, the local government did not present, at the end of 2013, the planned restructuring of the Przewozy Regionalne company, which unfortunately proved the inability of this body to agree decisively on the future of the company and the government finally withdrew from the declared financial support for its further debt. In 2013, the debt of the Regional Transport Company to the railway infrastructure manager (PLK SA) for access services became so high that in the political forums appeared and fixed the slogan that the Regional Transport Company is not only a matter of its owners, i.e. the Province Local Authorities, also a matter of government. The first effect of implementing this slogan is the government's willingness to pay another great debt, but also forcing PLK SA in early 2013, concluding with the company Regional Transports agreement, which plans to distribute the principal amount of PLN 384 million for the years 2009-2011 for monthly installments paid to July 1, 2017 and amortization of interest due to PLK SA from the principal amount of PLN 138 million. The collateral was pledged of 350 electric trainsets and locomotives belonging to the Regional Transports and on selected properties belonging to the carrier, including the headquarters of the company at Wileńska Street in Warsaw. Incidentally, it turned out very quickly that the commitments of the Regional Transport Company signed by its then Board of Directors were not credible - not the first time in any case - and already in August 2013 the company suspended the repayment.

While from 2012 to speak about a "repentance" owners of Regional Transport and attempts to "extract" from the government following large amounts of its debt reduction, it full of "sobering" Marshals on its further fate took place until the beginning of 2014 year, when it was once again listed the Management Board, who for a long time practiced financial equilibrium and appointed new President of the Board. From that point on you can only talk about real and not just branded efforts and actions of the company Regional Transport for internal restructuring, expansion of own market and stabilization of financial results. Too bad, but as the folk wisdom says, "better late than never".

\section{Railway passenger transport market in years 2011 - 2015}

The passenger rail transport market in Poland increased by approximately 16 million passengers (about 6\%) in 2011-2015, although rail transport operations decreased by 0.8 billion passenger kilometers (by 4.4\%) in those years. Indicates the average distance traveled by 1 passenger - see Table 1 . Tables 2 and 3 show the market shares of the individual railway undertakings operating between 2011 and 2015 in the regional rail transport segment, the number of passengers transported (Table 2) and the passenger transport activity (table 3). By analyzing this data in terms of the market share of Regional Transport Company, it is 
impossible not to notice that in the years 2011 - 2015 it lost a significant part of the market. While in 2011 the share of the company measured by the number of passengers transported was almost $41.5 \%$, in 2015 it fell to $27.4 \%$, i.e. by $14.1 \%$. In the same period, other carriers from the regional transport sector increased (Railways of Mazovia, Wielkopolska, Śląskie, Lower Silesia, Arriva) or stabilized their market shares (PKP SKM). Jointly in 2011-2015, regional rail carriers, excluding the Regional Transport Company, increased their market share by $12.3 \%$. Similarly, the market share of the Regional Transport Company measured by the transport activity was similar. In 2011 its market share was $36.5 \%$ and in 2015 it fell to 25.2 , which is $11.4 \%$. In these years, the remaining regional carriers increased their market share from $16.4 \%$ in 2011 to $27.4 \%$ in 2015 or $11.0 \%$.

Tab.1. Rail passenger transport in Poland in years 2011 - 2015. Source: www.utk.gov.pl

\begin{tabular}{|c|c|c|c|c|c|}
\hline & 2011 & 2012 & 2013 & 2014 & 2015 \\
\hline $\begin{array}{l}\text { Number of } \\
\text { passengers, } \\
\text { in millions }\end{array}$ & 264,5 & 273,9 & 270,4 & 269,1 & 280,3 \\
\hline $\begin{array}{l}\text { Transportation } \\
\text { work, } \\
\text { in billion paskm }\end{array}$ & 18,2 & 17,9 & 16,8 & 16,1 & 17,4 \\
\hline
\end{tabular}

Tab.2. Market shares of passenger carriers operating regional railways between 2011 and 2015, according to the number of passengers transported. Source: www.utk.gov.pl.

\begin{tabular}{|c|c|c|c|c|c|}
\hline & 2011 & 2012 & 2013 & 2014 & 2015 \\
\hline Przewozy Regionalne & $41,48 \%$ & $36,88 \%$ & $31,39 \%$ & $29,48 \%$ & $27,41 \%$ \\
\hline PKP SKM & $14,51 \%$ & $13,44 \%$ & $13,02 \%$ & $13,28 \%$ & $14,03 \%$ \\
\hline Koleje Mazowieckie & $20,57 \%$ & $21,58 \%$ & $23,09 \%$ & $23,26 \%$ & $22,56 \%$ \\
\hline Arriva RP & $0,92 \%$ & $0,91 \%$ & $0,92 \%$ & $1,71 \%$ & $1,53 \%$ \\
\hline $\begin{array}{l}\text { Koleje } \\
\text { Dolnośląskie }\end{array}$ & $0,34 \%$ & $0,67 \%$ & $0,90 \%$ & $1,34 \%$ & $1,86 \%$ \\
\hline Koleje Wielkopolskie & $0,21 \%$ & $1,22 \%$ & $2,00 \%$ & $2,69 \%$ & $2,63 \%$ \\
\hline Koleje Śląskie & $0,68 \%$ & $3,33 \%$ & $6,04 \%$ & $5,96 \%$ & $5,67 \%$ \\
\hline Koleje Małopolskie & & & & $0,01 \%$ & $0,64 \%$ \\
\hline $\begin{array}{l}\text { Łódzka Kolej } \\
\text { Aglomeracyjna }\end{array}$ & & & & $0,13 \%$ & $0,58 \%$ \\
\hline $\begin{array}{l}\text { Razem przewoźnicy } \\
\text { regionalni bez PR }\end{array}$ & $37,23 \%$ & $41,15 \%$ & $45,97 \%$ & $48,38 \%$ & $49,50 \%$ \\
\hline $\begin{array}{l}\text { Pozostali } \\
\text { przewoźnicy }\end{array}$ & $21,29 \%$ & $21,97 \%$ & $22,65 \%$ & $22,14 \%$ & $23,09 \%$ \\
\hline
\end{tabular}


Figure 1 presents data on the financial situation in the segment of passenger rail transport in Poland in the years 2011 - 2015. The data indicate that in the years 2011 to 2015, the trend to balance in the whole sub-sector income and expenses from operations, however full balance has not yet been achieved. However, already in 2014 the excess of operating expenses over revenues reached PLN100 million and increased in 2015 to a deficit of PLN 200 million. It should be noted, and this is confirmed by the data from Figure 2 that in the years 2014-2015 the company Regional Transport was no longer the main "producer" of the deficit, because in 2014 recorded a loss of only PLN 6 million, and in 2015 by realized a net profit (planned level, yet officially unconfirmed) at the level of PLN 39 million, thereby contributing to reducing the deficit of the entire passenger rail sector in Poland. These facts should be noted as particularly positive.

Tab. 3. Market shares of passenger carriers operating regional railways in the years 2011 2015, according to performed transport work. Source: www.utk.gov.pl.

\begin{tabular}{|c|c|c|c|c|c|}
\hline & 2011 & 2012 & 2013 & 2014 & 2015 \\
\hline Przewozy Regionalne & $36,53 \%$ & $34,22 \%$ & $30,56 \%$ & $30,01 \%$ & $25,17 \%$ \\
\hline PKP SKM & $4,97 \%$ & $4,70 \%$ & $4,77 \%$ & $5,35 \%$ & $5,62 \%$ \\
\hline Koleje Mazowieckie & $10,34 \%$ & $11,89 \%$ & $13,24 \%$ & $13,78 \%$ & $12,77 \%$ \\
\hline Arriva RP & $0,48 \%$ & $0,51 \%$ & $0,54 \%$ & $1,21 \%$ & $0,99 \%$ \\
\hline $\begin{array}{c}\text { Koleje } \\
\text { Dolnośląskie }\end{array}$ & $0,17 \%$ & $0,49 \%$ & $0,69 \%$ & $1,27 \%$ & $1,82 \%$ \\
\hline Koleje Wielkopolskie & $0,09 \%$ & $0,59 \%$ & $1,45 \%$ & $2,17 \%$ & $2,01 \%$ \\
\hline Koleje Śląskie & $0,30 \%$ & $1,63 \%$ & $3,85 \%$ & $4,02 \%$ & $3,59 \%$ \\
\hline Koleje Małopolskie & & & & $0,00 \%$ & $0,16 \%$ \\
\hline $\begin{array}{l}\text { Łódzka Kolej } \\
\text { Aglomeracyjna }\end{array}$ & & & & $0,10 \%$ & $0,42 \%$ \\
\hline $\begin{array}{c}\text { Total regional carriers } \\
\text { without PR }\end{array}$ & $16,35 \%$ & $19,81 \%$ & $24,54 \%$ & $27,90 \%$ & $27,38 \%$ \\
\hline Other carriers & $47,12 \%$ & $45,97 \%$ & $44,90 \%$ & $42,09 \%$ & $47,45 \%$ \\
\hline
\end{tabular}




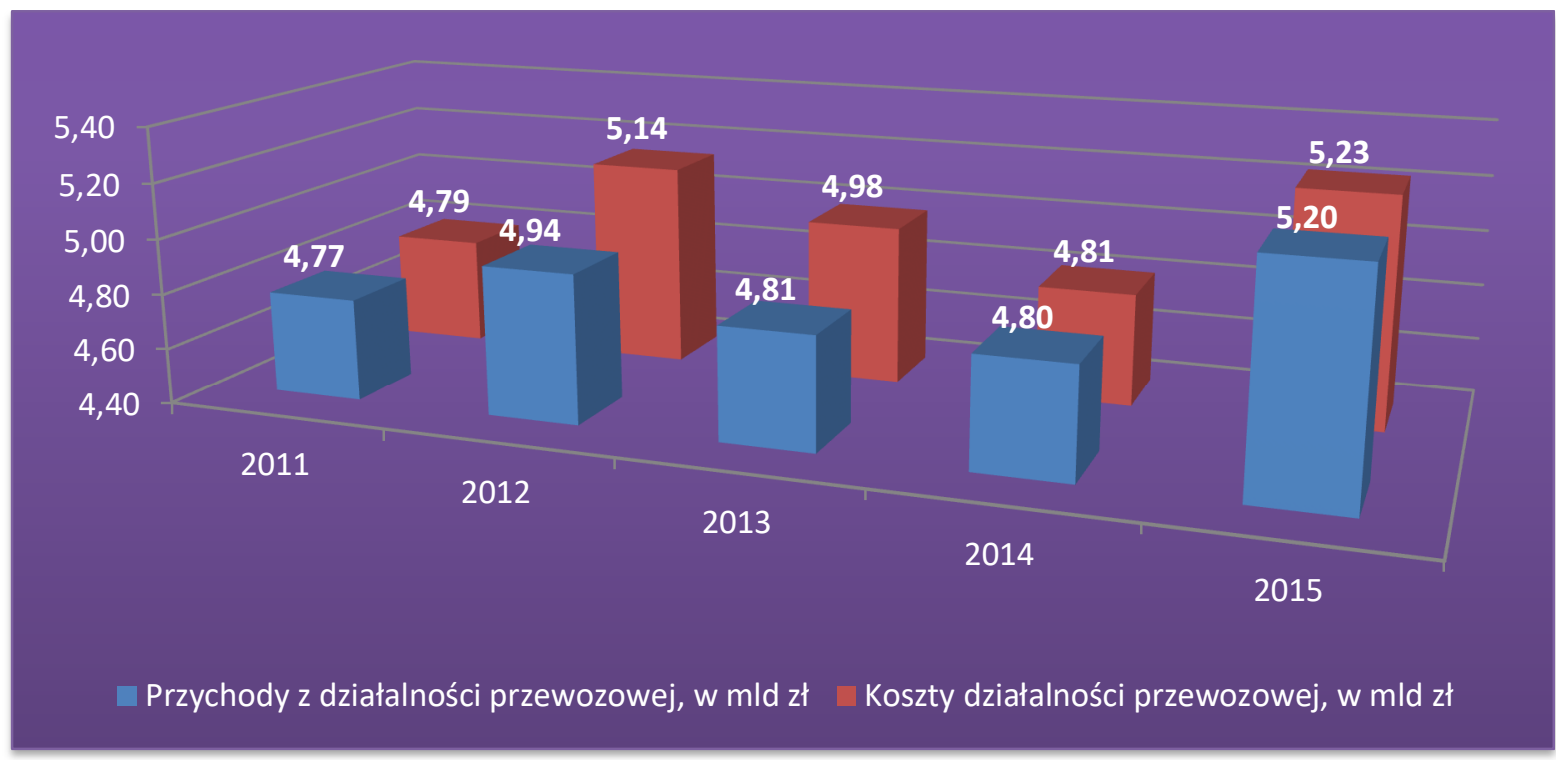

1. Revenues from transport activities and operating costs of railway passenger carriers in years 2011 2015. Source: Assessment of the functioning of the rail transport market and the state of rail traffic safety in 2015, p. 33 - www.utk.gov.pl
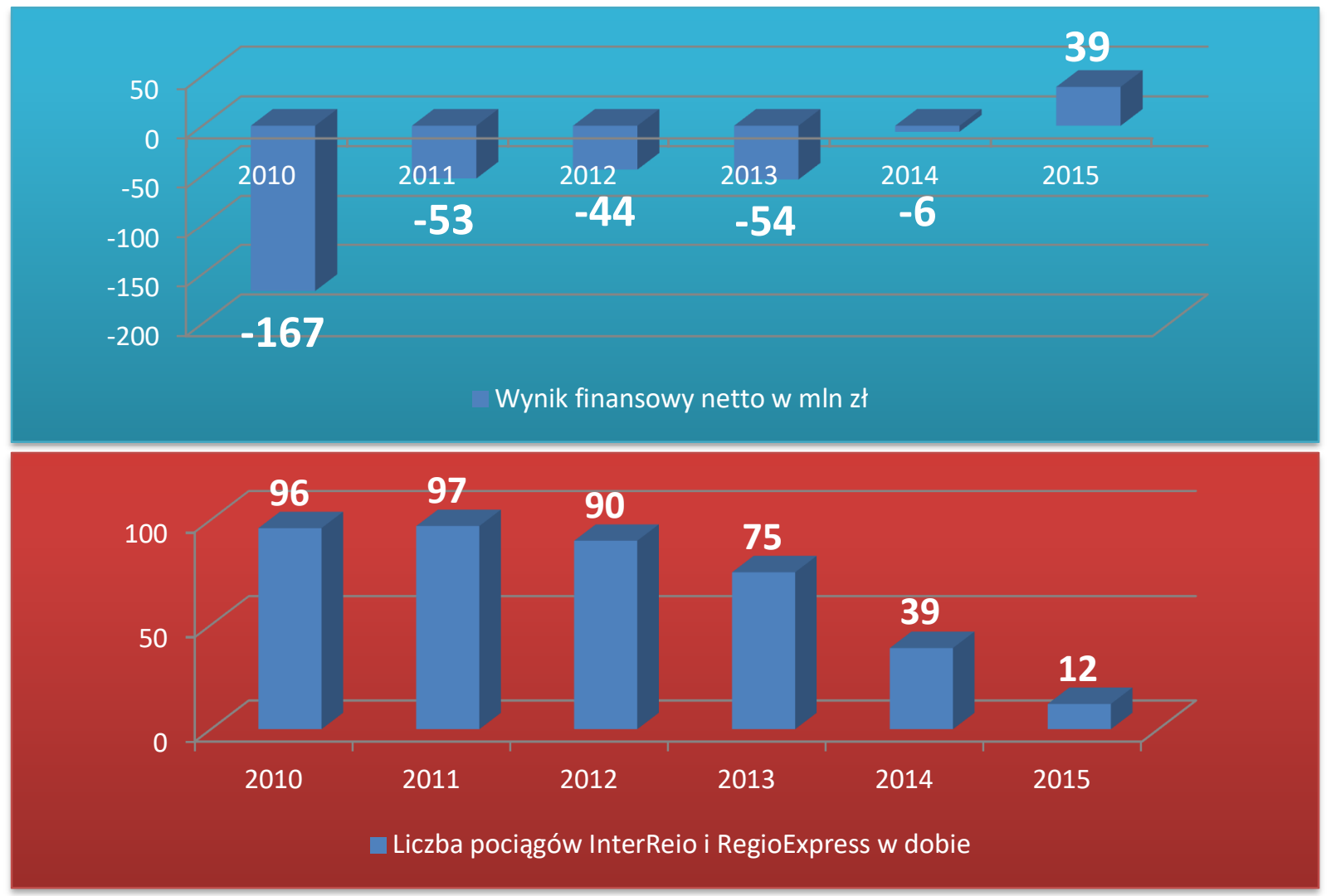

2. Financial results of the Regional Transport Company and the number of daily commuter trains InerRegio and RegioExpres in years 2010 - 2015. Source: Annual Reports of Przewozy Regionalne Company from years 2010 - 2014 - www.przewozyregionalne.pl and J. Madrjas, Przewozy Regionalne po raz pierwszy na plusie? - www.rynek-kolejowy.pl 21.09.2016. 


\section{Regional Transport Company - years 2014 - 2015}

The new Management Board, set up in February 2014, has made efforts to further its restructuring, both at the internal and external levels. In particular, with regard to internal changes, it was decided to reduce and then withdrawing the offer InterRegio trains and RegioExpress that are not being covered by funding under contracts for the provision of public services, clearly deteriorating financial results of the company's Przewozy Regionalne, leaving only 6 pairs of trains InterRegio in the relation Warszawa - Łódź (covered by the subsidy).

There is therefore a certain link between the reduction of the InterRegio and RegioExpress trains and the improvement of the financial results of the company, although it must always be borne in mind that the main factor shaping the company's financial results was and remains the costs of regional trains and the level of their subsidies under contracts provision of public services with Marshals of the provinces. Figure 2 shows the financial results of the Regional Transport Company in the years 2010 - 2015 against the background of the number of daily InerRegio and RegioExpress trains. In the company itself, 14 branches were created, which replaced the previously operating Regional Transport Workshops and were separated in the organizational structure of the Rolling Stock Repair Plant in Kruszewiec. This "branch" reform, however, was not entirely consistent, since the incorporated divisions were, in fact, a new copy of its former establishments, not so-called "Codex Branches" established under the Civil Code (and not the Commercial Code), as selfbalancing units, with their own separated assets and their own revenue - finance remains centralized. Nevertheless, the creation of branches was, in the author's view, a desirable step.

In parallel, the Company's Management Board undertook actions towards a new restructuring program, including a further debt reduction. The PO-PSL government in February 2014 declared support for the restructuring and debt restructuring of Regional Transport Company, and not only the government and the owners of the company, but also numerous experts and the social side were involved in the negotiations. In addition, the government acknowledged that the participation of the Agency for Industrial Development (ARP), which has the know-how associated with the restructuring of enterprises, is necessary in the process of financial restructuring. In this way, a new leader of the restructuring project of Przewozy Regionalne Company, which represents the government side, was established. During the negotiations two options were considered for further restructuring of the company. The first, driven by trade unions - envisaging the depletion of Regional Transport based on public funds and nationalization of PR (i.e. return to the model before December 2008) and the second, prepared by the Province Self-governments, that is regionalization, i.e. the establishment of regional companies by regional governments for regional railway transport and contribution to them in the form of assets of Przewozy Regionalne Company and human resources. This process was to be combined with the debt of the company based on public funds. Admission of each of these options and allocate adequate financial resources for debt reduction Przewozy Regionalne Company, was to present the company's recovery plan giving guarantees continued viability of regional transport system in Poland because the problems of Przewozy Regionalne affect passenger comfort and health of the entire railway market in Poland. As a result of the negotiations with the partners and preparatory work, the option of re-nationalization of the Regional Transport Company was adopted and in September 2015 the Agency for Industrial Development and Regional Transport signed a contract for its recapitalization. In practice this meant that ARP covered 1540607 shares in the increased share capital of Przewozy Regionalne $(50 \%+1$ share), covering them in cash in the amount of PLN 770.3 million. The decision to recapitalize Przewozy Regionalne was preceded by the company's preparation of a restructuring plan for the years 2015 - 2018, which assumes the recovery of long-term viability by Przewozy Regionalne. For this project, ARP received 
public funds and therefore one of the conditions for recapitalization was notification of public aid in the European Commission. The obtained funds from the recapitalization allowed the Przewozy Regionalne to implement the measures envisaged in the restructuring plan and above all to repay the debt mainly to PKP Group companies. The takeover by the government of ownership control over the company Przewozy Regionalne as well as the subsequent fourth major depreciation of this company, coupled with a marked improvement in its financial condition in 2014-2015 does not mean that the entire reform of regional railway transport in Poland has already been completed. The title of the question is the next paragraph of this text.

\section{What's next with Regional Transport?}

The market of the Regional Transport Company has been fundamentally transformed since 2009. The new Management Board set up in March 2016 continues the restructuring and repair program prepared jointly with ARP and submitted to the European Commission for notification. Currently, at the end of 2016, there are reasons to accept that in the coming years the economic and financial situation of the company will be stable and there will be no risk of debt repatriation to PKP Group companies. Moreover, the stable situation of the company is evidenced by the fact that in September 2016, a consortium of commercial banks and BGK awarded Regional Loans PLN $629 \mathrm{~m}$ credit to finance the modernization program of the company's rolling stock. With these funds, the company will upgrade 36 electric trainsets, buy 7 new and three rail buses. This is the largest rolling stock modernization program in the 15year history of Przewozy Regionalne. It should be emphasized in particular that its implementation was possible thanks to a previous debt reduction of PLN 770 million from the state budget. In the future, the company plans to additionally upgrade 200 traction units, as well as to modernize and build new technical facilities to operate the rolling stock (Kruszewiec, Skarżysko-Kamienna). This kind of business improvement activities are of paramount importance.

On the other hand, many railway market observers continue to question the target model of Regional Transport on the Polish railway market. The author of this text does not hide the fact that in the past when negotiating with the Marshals of the Provinces of the Agreement of 9 December 2008 on the so-called privatization, and later he was a supporter of the company's subdivision options, the one that Marshals push for in these negotiations with the government in the beginning of 2014. Ultimately, however, in 2015, it won the "renationalization" option, which has allowed it to stabilize its position and allow it to defend its market share, but, according to the author, this is not an optimal option for several reasons. Firstly, the state will never be a good owner of railway undertakings; secondly, the role of ARPs is, according to the name of the agency, to restructure companies rather than long-term ownership control over them; Fourth railway package and it will be one in Poland to implement.

This last problem requires some exposure. The European Commission has submitted the following proposals for the functioning of national passenger rail markets:

$>$ opening - by amending the Directive establishing the single European railway area 2012/34 - national passenger rail markets while retaining the possibility of limiting access in the event of a threat to the economic balance of the public service contract,

$>$ introduction of the obligation to organize a tender for public service contracts by amending Regulation 1370/2007 on the provision of public services in the field of road and rail public transport ${ }^{1}$,

\footnotetext{
${ }^{1}$ Public service contracts concluded on the basis of contracts awarded directly after the adoption of this legislative package could no longer apply until 31 December 2022.
} 
introduction of a minimum threshold below which orders can be awarded directly, which will allow the competent authorities to resign from organizing the tendering procedure in cases where the expected savings of public funds would be lower than the cost of the tender,

$>$ introduction of the obligation to develop public transport plans establishing public transport policy objectives, including general models for the provision and delivery of services in the field of transport,

$>$ provide incentives for Member States, competent authorities and railway undertakings to set up integrated ticketing systems at national level with regard to nondiscrimination requirements,

$>$ the commitment of the Member States in which there are no well-functioning markets, leasing of rolling stock, to take the necessary measures to ensure non-discriminatory access to the relevant railway rolling stock in order to facilitate the achievement of a high level of competition in the market of public service contracts.

Starting from the above general assumptions, the Commission proposed, inter alia, in the draft amendments to Regulation 1370/2007 ${ }^{2}$ :

$>$ the procedure for determining the public service obligations and the geographical coverage of public service contracts if the competent authorities consider that public intervention is necessary to ensure a politically desirable level of mobility in the territory for which they are responsible; public transport plans defining the objectives of public passenger transport policy and models of supply and performance of public passenger transport,

$>$ introduction of a threshold for maximum passenger rail volume under each public service contract in order to ensure effective competition - the maximum annual volume for a public service contract expressed in trains could be 10 million trains or one third of the total volume of domestic public passenger transport in the context of public service contracts, whichever is higher,

$>$ introduction of upper limits in the case of direct small orders and direct awarding of contracts to small and medium-sized enterprises - the competent authorities could decide to directly award contracts leading to the conclusion of public service contracts: (a) whose average annual value is estimated at ... less than 5 million EUR in the case of a public service contract covering rail transport services, or (b) which relate to the provision of public passenger transport services of less than 150000 kilometers in the case of a public service contract covering rail transport services,

$>$ the abolition of the possibility of action by the competent authorities decide whether to award the contract leading to the conclusion of a public service in transport by rail directly or by tender,

$>$ introduction the possibility to provide different railway undertakings with contracts for the provision of rail passenger transport services, including parts of the same network or package of routes,

\footnotetext{
${ }^{2}$ COM 2013/28.
} 
introduction of an obligation for Member States to provide effective and nondiscriminatory access to appropriate rolling stock to entities wishing to provide public passenger transport services.

In the context of the proposed systemic reform within the framework of the fourth railway package, it should be noted that Poland, as regards some of its components, is already prepared for implementation. In particular, thanks to the regulations of the Act on public transport of 2010, which entered into force in 2011, there is already a system of integrated transport plans in Poland. Secondly, a significant part of the modern rolling stock used for regional rail transport is owned by the Marshals of the Provinces. This rolling stock is currently leased or leased to the Regional Transport Company, which does not yet own its own rolling stock, and in the future, this form of ownership of rolling stock will foster the creation of so-called the rolling stock pool referred to in the fourth railway package. Thirdly, the fourth package recommends the sharing of transport tasks in the areas concerned in such a way as to include parts of the same network or package routes, which in Poland is already a common practice. The most difficult part of the fourth railway package will undoubtedly be the requirement to leave the so-called direct procurement of railways in regions, for the purpose of organizing open tenders and of the international character. On this issue, there is still a debate in the European Union and many countries are doing all they can to push this regulation away as far as possible. An open tender means that, for example, in Poland, railway companies owned by the Voivodeship Authorities would not necessarily be beneficiaries of public service contracts in the area of their "self" government. One of the Polish voivodship's open tenders for regional rail transport wins a company such as Dutch, German or Italian. On the other hand, it is easy to see that with the present entity and ownership structure on the Polish regional railway market, the Przewozy Regionalne Company, which already has the appropriate staff of railway operators and know-how, would have a good chance of having a good rolling stock. However, the fourth package assumes that rolling stock can offer public authority in the context of an open tender that is being used by the company. Moreover, it can be seen that in the short term the Przewozy Regionalne Company may gain another competitive advantage in the form of offering maintenance services and repairing passenger rolling stock in its own facilities. It does not yet require EU certification, as is the backfill of freight wagons, but it can be expected that in the medium term the European Union will introduce a mandatory certification of the technical infrastructure of rolling stock.

The above comments may, though not necessarily, lead to the conclusion that the current entity and ownership structure on the Polish passenger rail market may undergo further changes and transformations. The author of this text sees here one true target solution, which requires the use of the "privatization" of companies in the entire passenger sector, which is disgusting for many Polish politicians and trade unions. Of course not now and not so fast, because part of the politico class is not prepared for such a solution. However, according to the author, the marshals of the provinces either on their own initiative or will be forced to withdraw from investment in railway undertakings ownership and carry out their privatization, i.e. the privatization of railway companies. On the other hand, the Industrial Development Agency will also, once again, withdraw from its budget rather than invest in the capital of the Regional Transport Company, since it has not decided on a better, though more difficult, implementation of its debt-to-equity ratio. In this regard, the author continues to maintain his view that maintaining a long-term, state-owned, central railroad company in the region is not rational. 